\title{
Resilience in Talcahuano, Chile: appraising local disaster response
}

Resilience in Talcahuano, Chile

\author{
Karen Elisabeth Engel and Jeroen Frank Warner \\ Department of Sociology of Development and Change, \\ Wageningen Universiteit, Wageningen, The Netherlands
}

\begin{abstract}
Purpose - The purpose of this paper is to present the findings of a qualitative and exploratory study aimed at learning more about the local forms of resilience that emerged in two localities (one rural and one urban locality) in Talcahuano, Chile, in response to the major earthquake and devastating tsunami that hit them on February 27, 2010. Design/methodology/approach - To ensure that people's experiences remained leading throughout the study, data were collected in the field by the first author over a period of 13 months using a variety of qualitative methods. The primary methods were observation, participation and semi-structured interviews with a variety of actors, ranging from community members to local leaders and emergency professionals. For the analysis, a scheme was used that categorizes manifested resilience using two dimensions: damage and responsiveness. Since this scheme has been mostly used to evaluate tree populations, it was adapted to fit the appraisal of a social system.

Findings - The findings suggest that damage levels in the two communities were similar, but that the responsiveness was not. One locality revealed high levels of resilience, while the other exposed increased susceptibility to future similar events.

Originality/value - This research initiative was relevant because it exposed actual resilience. Also, the specificities of the findings enable insights about prevalent vulnerability, in particular the local capacity of response, and that can be used to elaborate concrete earthquake/tsunami disaster scenarios and design local disaster risk reduction interventions.
\end{abstract}

Keywords Disaster, Community response

Paper type Research paper

On February 27, 2010, a M8.8 earthquake struck the south-central region of Chile and triggered a ravaging tsunami. Talcahuano was one of the most heavily affected cities (hereafter these 2010 disaster events will be referred to as $27 \mathrm{~F}$ in line with local usage).

To learn more about local responses to $27 \mathrm{~F}$ and earthquake/tsunami vulnerability in Talcahuano, a qualitative resilience assessment was devised and applied to two localities in Talcahuano (see Figure 1). Specifically, we used a scheme inspired by Bellingham et al's (1995) which we adapted to fit the appraisal of communities, i.e. social systems, by modifying the indicators. The scheme uses two dimensions to assess resilience, namely, damage and responsiveness. This made it straightforward and practical to use for the purpose at hand. This paper presents the findings.

This study was part of a larger project that looked into the earthquake/tsunami vulnerability that people in Greater Concepción (GC), Chile, experienced and which were laid bare by $27 \mathrm{~F}$. The exploratory nature of this project and our view that experiences cannot be measured, only understood moved us to select a qualitative methodology. Data were

(C) Karen Elisabeth Engel and Jeroen Frank Warner. Published by Emerald Publishing Limited. This article is published under the Creative Commons Attribution (CC BY 4.0) licence. Anyone may reproduce, distribute, translate and create derivative works of this article (for both commercial \& non-commercial purposes), subject to full attribution to the original publication and authors. The full terms of this licence may be seen at http://creativecommons.org/licences/by/4.0/legalcode

The authors would like to thank the Netherlands Organization for Scientific Research (NWO) and Wageningen University, in particular the sub-division Sociology of Development and Change, for making the study, from which this paper is part of, possible.

Received 11 July 2018

Revised 11 November 2018

22 February 2019

8 March 2019

12 March 2019

17 March 2019

Accepted 17 March 2019

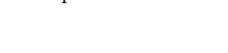

. 
$\mathrm{DPM}$
28,5

\section{6}

Figure 1.

Visualization of Talcahuano's (Chile) geographical location (elaborated with Google)

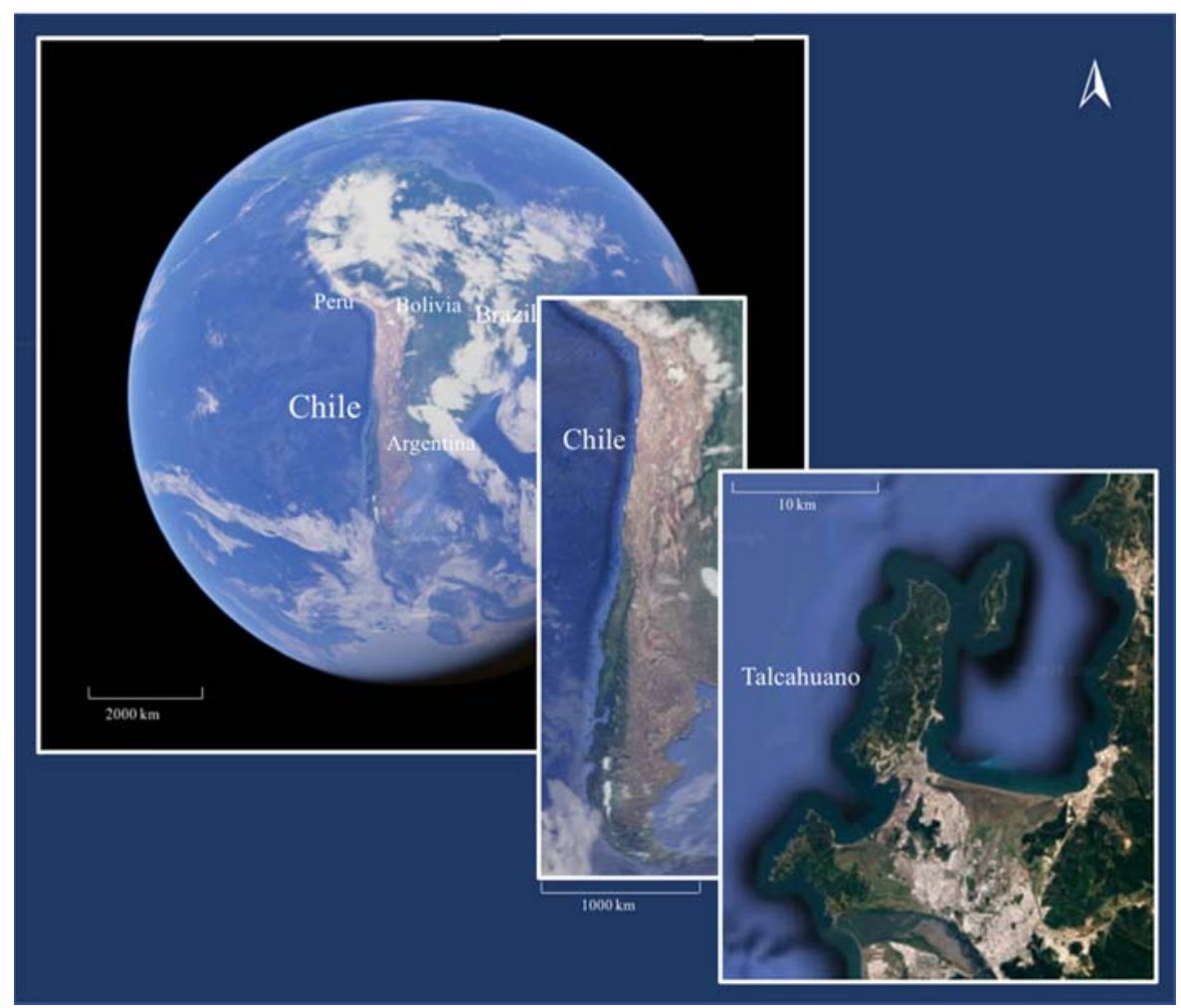

collected mostly in "the field" by the first author. She spent over a year collecting data, between 2012 and 2016. Various sources, such as (in-depth) interviewing, observation, participation and document review, were used. For the collection of specific complementary information, a small number of group interviews were conducted. Because of the sensitive nature of most interviews involved we learned that focus group interviews could only be used to get non-sensitive complementary information. For instance, to learn more about the functioning of the local firefighters as a professional organization and specificities about the way the Mapuche community responded as a collective.

To safeguard the focus on participants' experiences, most interviews were semi-structured and participants would lead the "conversation." Through snowball sampling a pool of over 150 respondents was achieved with people from different socioeconomic backgrounds, ages and even ethnic backgrounds. Approximately 10 percent were key informants. Most of the participants were community members; however, scholars, governmental officials and (emergency) professionals also participated. Key informants included a political leader, local leaders (4), practitioners (4), community members (4), emergency professionals (4) and a scholar. Validation of data was achieved through triangulation, member checking and prolonged time in "the field." The need to ensure our participants' confidentiality motivated us to opt for an unorthodox way of citing participants. It is highly impersonal as we cite selections as "raw data" and reference them with merely the year of the interview.

We build on Engel et al's (2014) research on disaster subcultures, which showed that even within a few miles, communities can adapt differently to the same hazard and cultivate disparate cultural reservoirs to deal with the same hazard. Central to this study was therefore 
that local responses and damage patterns should be appreciated and similarities should not be assumed because of proximity.

The paper is organized as follows. First, we discuss this paper's conceptual building blocks. Then, we present the analytical scheme used to appraise resilience[1]. Third, we present and synthesize our findings. Before concluding, we discuss critical issues relevant for future research and disaster risk reduction efforts.

\section{Resilience: a descriptive approach}

Hazardous events remain important tests to communities' limits and ingenuity. In light of this, "resilience," as a concept, gained ground and is "framing [more and more] current thinking about sustainable futures in an environment of growing risk and uncertainty" (Mitchell and Harris, 2012, p. 1). Even though there is no agreed upon definition, it is generally associated with a system's capacity to "bounce back," "adapt to," "cope," "withstand," "resist" and "recover" from adversity (Bruneau et al., 2003; Aldunce et al., 2014; Manyena, 2006; Warner and Engel, 2014). While some consider it the flipside of vulnerability, we argue that it is related to vulnerability because it affects a system's capacity of response to disturbances and subsequently influences the extent of the change brought about (Gallopín, 2006) (see Figure 1). Throughout this paper, resilience is regarded an attribute of vulnerability which is tightly linked to capacity of response. It is a systemic quality which is manifested in the face of (unexpected or unpredictable) change. As Walker et al. (2004) state, resilience refers to a system's ability to absorb and adapt to change and maintain integrity. As a concept it has been welcomed because it "is associated with the proactive approach of harnessing the strengths of communities, as distinct from the traditional reactive, top-down approaches to DRR associated with the deficit model of vulnerability, where disaster victims are seen as 'helpless' (Manyena, 2016, p. 42).” Also, it is a readily recognizable concept that allows people from different disciplines and communities of practice to work across silos (Bahadur et al, 2010; Sudmeier-Rieux, 2014; Mitchell and Harris, 2012).

This paper considers resilience a systemic quality that emerges from a community's collective performance in the face of (unexpected or unpredictable) change. It reflects the system's ability to self-organize, adapt, resist, take advantage of opportunities to reorganize, access resources, adapt and prevent structural changes. The main challenge is "to conserve the ability to adapt to change, to be able to respond in a flexible way to uncertainty and surprises. And even to create the kind of surprises that open opportunity (Gunderson and Holling, 2002, chapter 2)." Central to resilience is therefore an acceptance that "things change - and to ignore or resist this change is to increase our vulnerability and forego emerging opportunities" (Walker and Salt, 2006, chapter 1). Resilience is different from adaptability. Resilience is a systemic quality and adaptability refers to the human ability to influence resilience: people are not destined to simply react, they can be proactive, adjust their condition and affect resilience.

Our application of resilience is descriptive rather than normative in order to learn more about communities' responses to hazard-induced changes. A descriptive approach seems more conducive to insights about communities' actual response capacity that can uniquely inform routes toward disaster risk reduction. Also, we do not consider resilience a good in and of itself since it can be a major impediment to transformative changes needed to address root causes that make communities sensitive to perturbations.

\section{Appraising forms of resilience: the model}

To categorize manifested forms of resilience in response to stress, Bellingham et al. (1995) devised a practical scheme in which resilience is a function of damage and responsiveness and which classifies populations into four groups: resistant (limited damage, limited response), usurper (limited damage, significant responsiveness), resilient (significant damage, significant responsiveness) and susceptible populations (significant damage, limited responsiveness) (see Figure 2). While Bellingham et al. (1995) and later Batista and

Resilience in Talcahuano, Chile 
DPM 28,5

588

Figure 2.

Vulnerability vs resilience

Table I.

\section{Resilience} classification as presented by Bellingham et al. (1995)
Platt (2003) used this model to classify tree populations, it was adapted by Cai et al. (2016) to typify communities' levels of resilience in the Lower Mississippi River Basin. They considered this scheme "valuable because it is a straight-forward way of identifying and breaking down a system's response to adverse change; stress, i.e. appraise resilience when it manifests itself (Cai et al., 2016, p. 3).” In Cai et al.'s resilience inference measurement model "[...] vulnerability refers to the latent relationship between exposure and damage, whereas adaptability indicates the latent relationship between damage and recovery [...]. If a community [...] has high exposure to a hazard but sustains low damage, then the community is considered to have low vulnerability. Similarly, if a community sustains high damage but has a favourable recovery (e.g. return of population, infrastructure, or health status), then the community is considered to have high adaptability. Resilience is measured based on the two relationships. A high vulnerability/adaptability ratio is considered low resilience, whereas a low vulnerability/adaptability ratio is considered high resilience"[2].

For our study, we decided to stay true to the original model and use both dimensions (damage and responsiveness) as well as the classification of resilience (susceptible, resilient, resistant and usurper) (see Table I and Figure 3).

We adapted the model and operationalized damage and responsiveness to suit social systems. Guided by available literature, we opted for indicators that in our view give a comprehensive picture of the nature of resilience that emerges in response to change (Anderson and Woodrow, 1998; ECLAC, 2003; Wisner et al., 2004; Jovel and Muhadar, 2010; CADRI, 2011; De Groeve et al., 2014; EC, 2015; Parsons et al., 2016; Scott and Few, 2016; Scott et al., 2016; Toseroni et al., 2016). The indicators are presented in Table II.

Then, based on available data, we scored the localities on a three-point scale (low, medium and high). This was done based on the communities' evaluation of the indicator and scores are therefore shaped by the value that the community gave to the loss or responsiveness component at hand. Take human loss, for instance. The rural community regularly loses people to "the sea." As a result, the losses from the tsunami due to, according to them, stubbornness and vice, are downplayed and not considered disastrous even though percentage wise, it is significant. The impact of this on the scoring is kept limited, but we did choose to let it affect it. The following paragraphs present the findings of our resilience appraisal.

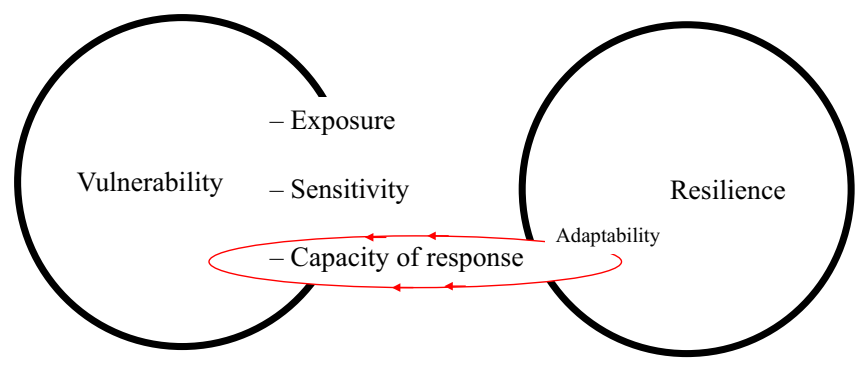




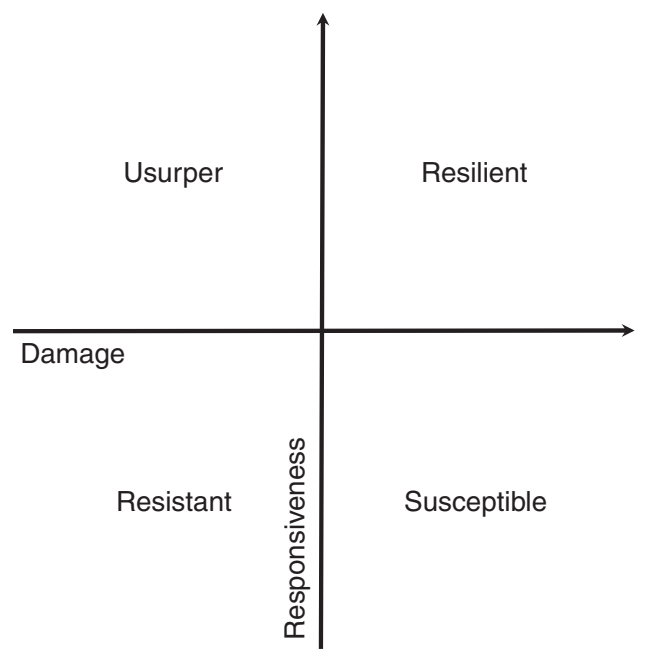

Resilience in Talcahuano, Chile

\begin{tabular}{|c|c|c|c|}
\hline \multicolumn{2}{|l|}{ Usurper } & \multirow{2}{*}{ Resilient } & \multirow{2}{*}{589} \\
\hline Damage & & & \\
\hline Resistant & 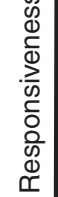 & Susceptible & $\begin{array}{r}\text { Figure 3. } \\
\text { Visualization of } \\
\text { Bellingham } \\
\text { et al.'s resilience } \\
\text { classifications }\end{array}$ \\
\hline
\end{tabular}

Damage

Human loss

Social sector loss

Social infrastructure loss

Economic loss

Cross-sectoral loss

Responsiveness

Cross-sectoral response

Mobilization of actors and resources

Self-organization, cohesion and ability to address needs

Openness

Accountability
Population affected, including death, injury, missing and indirect effects Social services, such as health and education services Housing and human settlement

Social infrastructure, such as social cohesion

Damage to property, economic activity or infrastructure (anything considered structure that provides a service, such as water supply and sanitation, electricity supply, transport and communications)

Economic activity, i.e. the productive sector (agriculture, industry, commerce, tourism)

Damage on public administration, financial sector and the environment

Institutional responses

Mobilization of a diverse pool of actors and resources, including human, social, economic and political resources

Self-organization (including leadership), social cohesion and the ability to address specific needs on a community and household level Openness to change with the purpose of learning and/or adapting Right holders and duty bearers deliver on their obligations
Table II.

Overview damage and responsiveness indicators

\section{Post-event resilience analysis: urban vs rural Talcahuano}

Talcahuano is the second largest port in Chile. It serves as the hub for the provision of logistic, maritime and port services for GC, the second largest conurbation in Chile, and the south. The fishing industry is one of the principal economic sectors (UNDP and Municipality of Talcahuano, 2011, pp. 14-15), but it also hosts a Chilean Navy base, 20.5 percent of the population of GC, and industrial plants related to steel, oil refinement, petrochemicals, gas and cement. In 2010, Talcahuano was affected by both the earthquake and the tsunami (see Figure 4).

The number of fatalities was relatively low at 37 deaths (21 due to the tsunami), the physical environment was ravaged and lives seriously interrupted (UNDP and Municipality of Talcahuano, 2012). This paper takes a closer look into "the Plain," an urban locality that includes residential areas like Salinas, El Morro and Talcahuano Center, and "the Bays" a 


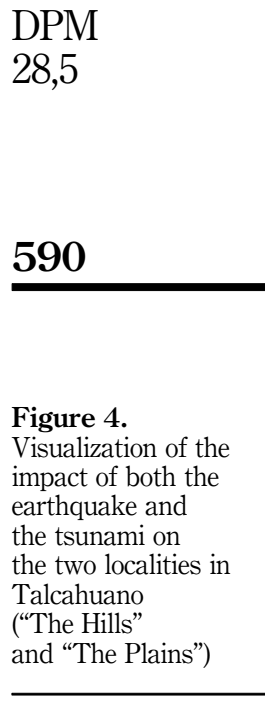

DPM

28,5

Figure 4.

Visualization of the impact of both the earthquake and the tsunami on the two localities in Talcahuano (The Hills" and "The Plains")

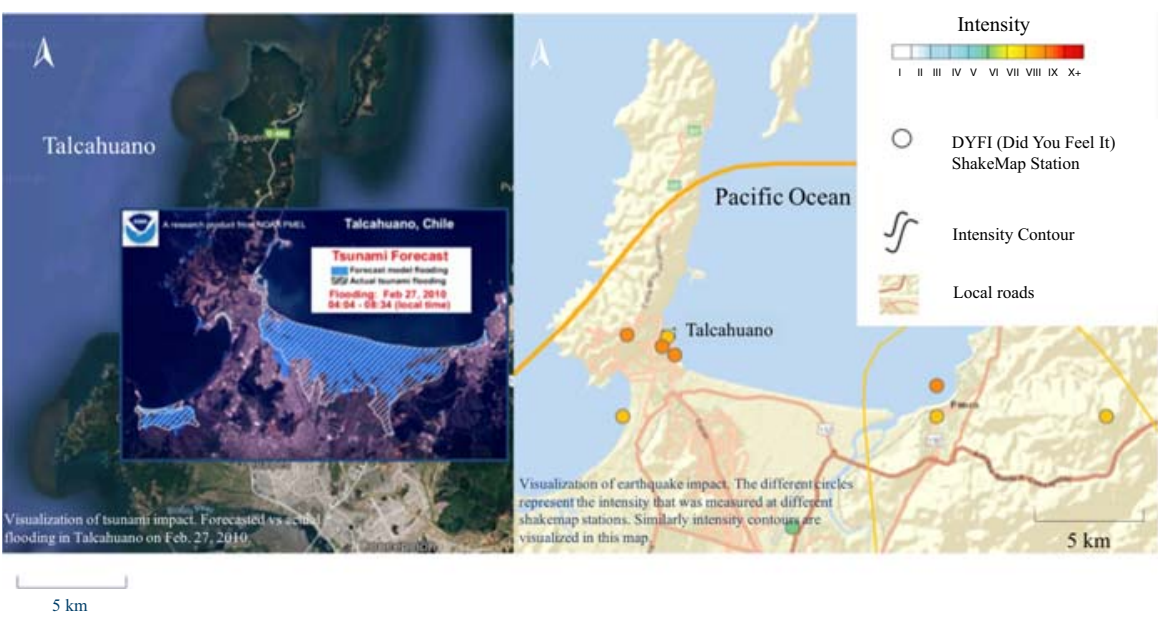

Note: Tsunami visualization realized through the use of NOAA (2010) and Google maps materials and the earthquake visualization created with USGS (2018) and Google materials

rural locality that includes the bays Canteras, Candelaria and Puerto Ingles. "The Plain" and "The Bays" (see Figure 5) are categories that respondents used throughout the interviews. To maintain the analysis and findings close to our respondents' experiences, we decided to borrow these terms.

\subsection{The localities}

Urban Talcahuano or "the plain". Talcahuano consists of two types of territory: a peninsula and an isthmus. The peninsula is high ground and the isthmus, known as the isthmus of the Low Lands or colloquially as "The Plain," is mostly low-lying land that includes wetlands. "The Plain" houses approximately two-thirds of Talcahuano's population (Engel, 2016) as well as the city-center and most governmental, industrial and commercial entities. Even though historically it was prohibited to use the wetlands for residential purposes (Interviews Talcahuano, 2012-2014; Vidal and Romero, 2010, p. 1; Bucci, 2013; Engel, 2016), today it hosts middle-class neighborhoods.

Rural Talcahuano or "The Bays". "The Bays" covers three small bays that hosted roughly 107 families when $27 \mathrm{~F}$ struck. It is situated on the Tumbes peninsula beyond the larger Tumbes Bay (See Figure 5). The peninsula is owned by the Chilean Navy, but colonization was tolerated. Their principal economic activity is artisanal fishery, principally the extraction of seafood and seaweed. Since these bays were tolerated, but never formalized, they did not have access to public goods such as drinking water, electricity or transportation. Life, particularly in winter, could be tough. High tides would, for instance, cut them off from "the continent" for vast periods of time. Despite this, interviewees stressed they enjoyed the tranquility, beauty and quaint character of the bays. These bays were their space and as a community they overcame the challenges and enjoyed the fruits de mer these bays had to offer. Social cohesion and solidarity were high.

The following sections present our comparative analysis of the localities. We look into both localities' damage and responsiveness to provide more insights into the type of resilience that manifested in response to $27 \mathrm{~F}$. To give a better idea of the way that $27 \mathrm{~F}$ affected Talcahuano, we have included Figure 5. 


\subsection{Human loss}

Table III presents the outcome of the damage analysis. In terms of human loss, both localities suffered. Inhabitants of both localities were adversely affected and loss included loss of life. "The Plain" loss was due to both the earthquake and the tsunami. There are hardly any reliable and specific statistics, so exact data per localities cannot be provided (Sehnbruch, 2017). From what is known, "the Bays" lost two members (approx. 2 percent of the population). Our data suggest that this loss was lamented but not exceptionally so: it was not the first time "the sea took from them (Interview Talcahuano, January 28, 2013)." Also, in their view the deaths were related to personal decisions shaped by stubbornness and vice (one refused to evacuate because he wanted to go safeguard his boat and the other refused because he was intoxicated and believed nothing would happen).

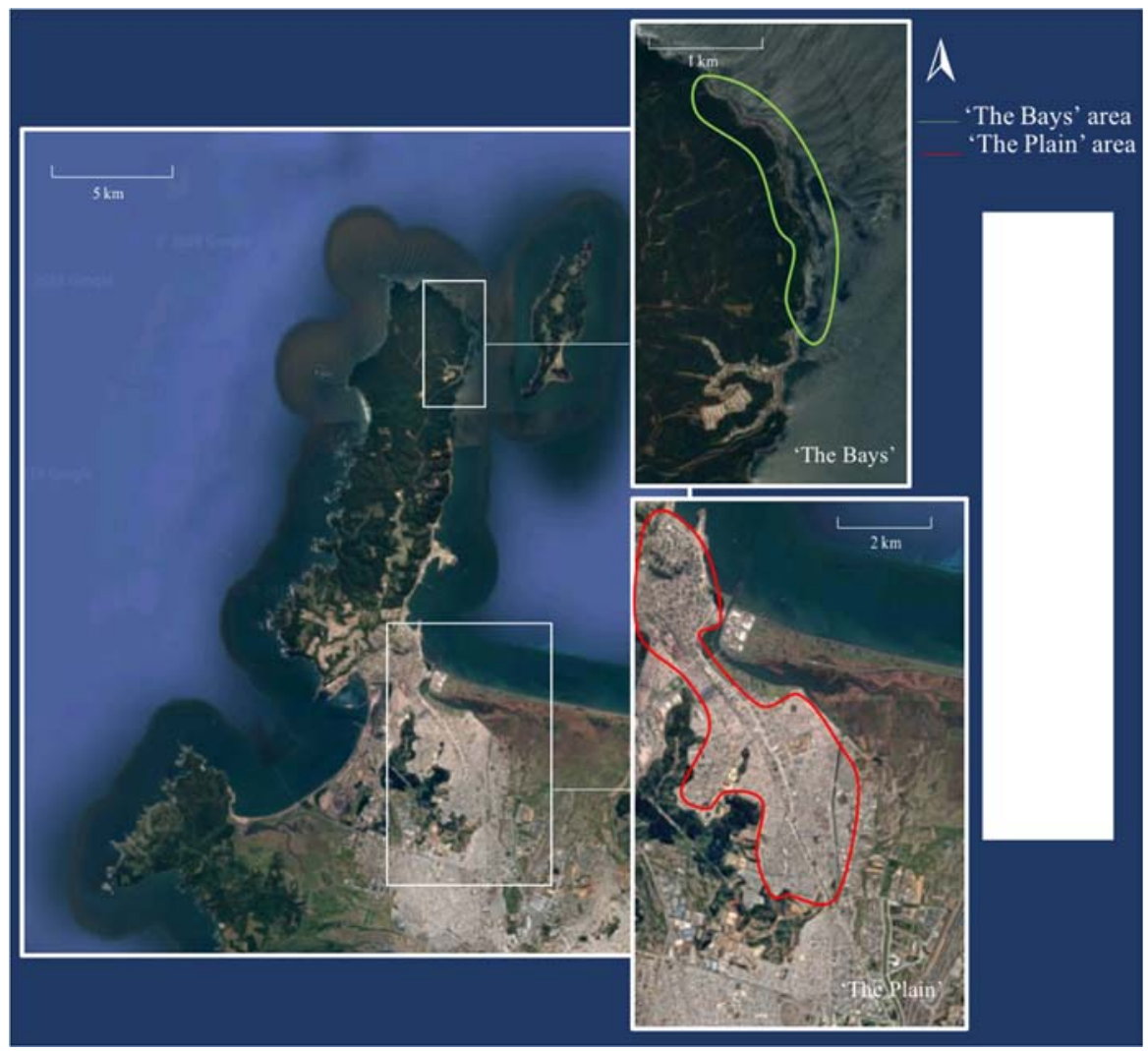

Resilience in Talcahuano, Chile
Figure 5. Localities
Human loss

Social sector loss

Social infrastructure loss

Economic loss

Cross-sectoral loss
L

M

L

$\mathrm{H}$

M
L

$\mathrm{H}$

$\mathrm{M}$

$\mathrm{H}$

M
Table III.

Damage analysis: urban vs rural Talcahuano 
$\mathrm{DPM}$ 28,5

Human loss in the urban locality was different. Comparatively, less lives were taken, but impact was greater (UNDP and Municipality of Talcahuano, 2016). Our findings suggest loss of lives was lamented more because it is considered the result of misinformation from the government; a trusted actor. People who had decided to evacuate were told to go back home because a tsunami had been discarded:

[Son:] The authorities had said that a tsunami had been discarded. The governor, the president, everyone said the tsunami was not coming. The police came by with a megaphone and I asked them and they told me not to worry [...] [Mother:] we hear the sound of the tsunami and my husband opens the door to look. I saw the water coming in with great force and my 'old man' disappears [...] I take a deep breath and I throw myself up to get somewhere I can breathe [...] I keep myself afloat as I endure the blows from furniture floating in the room [...] my house was a traditional, colonial house, with just one floor, but very high, almost 6 meters, ceilings. (Interview Talcahuano, 2012)

On the radio they were saying to stay calm and that a tsunami had been discarded. Then you listen to what the news says. This is when people started coming back, repeating what they had heard. Also, the firemen were saying through their megaphones to return home because there was no tsunami warning. I listen to people I consider informed. One always takes notice of what the police or the firemen say, right? [...] Then suddenly a man runs towards us, yelling "run, the sea is coming." That's when the most terrible starts. (Interview Talcahuano, 2014)

Unlike "The Bays," respondents of "The Plain" were also directly affected by the waves. People were "taken" by the waves. This left them injured and emotionally impaired (interviews Talcahuano, 2012-2016).

\subsection{Social sector loss}

Both communities enjoyed the same social services, so when these services were interrupted both were affected. Also, both localities saw their homes affected. The rural locality, however, lost their "place." The navy disallowed their return to "The Bays." Since their personal, social and cultural identity were heavily intertwined with their environment, the impact of this decision was significant. Families would await the return of their men there and, when home, men would jointly fix their netting. More importantly, they had direct access to the sea that provided them with a livelihood: seafood and seaweed.

In addition to losing their "space," they were relocated to emergency camps situated in a humid golly in the Tumbes Bay. This brought a lot of grief. They lived in "emergency housing" (small wooden prefabricated dwellings) meant to provide temporary shelter for no more than a few weeks, for over five years. Since the emergency structures were not constructed for long-term accommodation they started to disintegrate. This made life in a humid golly that was cold and prone to flooding distressing. On top of this, they could not see the sea from this gully. After five years they were offered permanent housing in a newly developed neighborhood on top of a hill in the Tumbes Bay. This resettlement meant giving up their vicinity to "their" sea; "their" beaches. At the same time, they were glad they could at least see the sea.

Residents from the "the Plain" mostly saw damage to the social sector. Some homes were lost and most homes were negatively affected by the tsunami. The true extend of the problem remains unclear. It is for instance unknown the long-term effects that salt-water penetration will have on the concrete and masonry constructions.

\subsection{Social infrastructure loss}

In terms of social infrastructure, the urban locality lost little. Social cohesion was minimal and $27 \mathrm{~F}$ did not change that. Noteworthy is the adverse impact that state-led recovery initiatives had on built environments. People were not resettled, but their built environments that had reflected the residents' historical, cultural and social setting and had organically developed over time were completely altered. The state imposed a standard layout as well as 
standard state-designed tsunami-proof dwellings without any consideration of residents' social and cultural needs. This left people feeling estranged and provoked a number of them to move away. This had a negative impact on the social infrastructure but it was not an overriding consequence felt allover "the Plain."

The rural locality experienced negative impact on their social integrity. Their relocation meant moving to a space shaped by the state. Also, it did not reflect their social and cultural needs. The distribution of homes, for instance, was done on the basis of "objective" criteria. Houses were allocated on the basis of households' active participation in the recovery process. This meant that households that had been financially and actively engaged in the process were allowed to choose a house first:

All houses are the same. Only those suitable for the handicapped are designed differently. Everyone will get a house, but we have a policy that the fifty that have most regularly attended meetings and paid their monthly contributions can chose first. It's not that we need the money. It's only 500 pesos per month. We could get by with only 10 families paying. Since all we need is some money for our bus fare and phone plan, but we want to have some extra for collective expenses. Also, it wouldn't be fair that some pay and others do not. We work for all two hundred families, not just the ten that pay. But most have paid. Some are just a bit lazy and think the treasurer lives too far away so they pay whenever they attend meetings. (Interview Talcahuano, February 5, 2014)

This led to a completely different organization of the neighborhood, and people were left with neighbors that they otherwise might not have had. According to respondents, these types of changes have affected social cohesion negatively as organically grown social units were disrupted. Also, since the community no longer inhabits a space ridden by adversity, they no longer experience problematic situations requiring collective solutions. For instance, before $27 \mathrm{~F}$, in Winter the residents could be locked in for weeks. Such periods of isolation would bring the community together. A good example of this is how they would make sure people would in these instances be brought to the hospital:

[...] [where we lived] ambulances could not come, so whenever anyone needed to get to an ambulance we would use towels and clothes to build a stretcher and take them up to where the ambulance could come. (Interview Talcahuano, February 5, 2014).

This implies fewer instances of collaboration and solidary and this is also negatively affecting social cohesion.

\subsection{Economic loss}

The tsunami affected Talcahuano's entire productive sector. Among others, vessels, the port, customs, numerous public and private buildings, the naval base and ASMAR shipyards were severely damaged. These were the backbone of Talcahuano as a logistical, maritime and port services hub. Also, the entire fishery sector, both industrial and artisanal, was devastated and paralyzed for months as boats had crashed onto shore and fish-processing plants were badly damaged (UNDP and Municipality of Talcahuano, 2011, p. 16). This led to job scarcity and unemployment.

For "the Bays," this damage was significant. They were solely dependent on the fishing sector, especially on artisanal fishery (small-scale, low-capital fishing undertaken by individual households for commercial and/or subsistence reasons). So, when the tsunami hit entire "businesses" were lost: boats, tools, investments and capital.

Economic loss was worsened by cross-scale interactions. Cross-scale interactions refer to the (hierarchical) dynamics between complex systems' natural and social components (Walker and Salt, 2006). Most noteworthy cross-scale interaction was the on-going declining fish supply due to overfishing and the new fishing law that was put in place in 2013. This fishing law favors the industrial fishing industry over traditional, artisan fishing. This was particularly

Resilience in Talcahuano, Chile 
$\mathrm{DPM}$ 28,5

594

unfortunate for "the Bays." "The Plain" also experienced adverse cross-scale interactions. The neo-liberal economic system that is dominant throughout Chile, for instance, left households on "the Plain" increasingly sensitive to shocks (Solimano, 2014, p. 74; Engel, 2016) (see Figure 3), mostly because of their limited access to resources necessary to recover (Engel, 2016).

The urban locality suffered more infrastructural damage. Since households were depended on this infrastructure, it disrupted their lives. In fact, participants conveyed that as soon as most infrastructures were recovered they could return to normalcy. Since the rural locality never had had access to such infrastructure impact of its loss was negligible.

Finally, physical damage to housing and personal property translated into substantial financial losses. Material possessions were lost and homes with salt-water contamination were weakened. Economic damage on a household level was nevertheless more extensive in "The Bays." Approximately half of the residents lost everything and the other half lost key occupational assets vital to most their livelihoods.

\subsection{Cross-sectoral loss}

Since both localities depended on the same public administration infrastructure, they were both equally affected by its collapse. Employees were residents of Talcahuano, so they were personally affected. Also, most physical infrastructure (buildings, archives, ICT, etc.) was hit by the tsunami and lost. This compromised the delivery of any public service. Interestingly, today most offices continue to be located on tsunami-exposed land.

What was different for the two localities was damage to heritage. With the loss of "place," the rural locality lost an important part of theirs. Being away from the sea-side and having to look toward other livelihood options than artisanal fishery is changing their cultural identity. Previously, both men and women worked in artisan fishing. Today, however, the declining fish stock in combination with access to more job opportunities is moving women to seek labor elsewhere. This translated in our analysis to greater cross-sectorial losses for the rural locality than for the urban one.

Finally, we would like to discuss environmental damage. In terms of contamination, the urban locality has been affected more extensively. Their land was covered in oily waste containing high concentrations of bacteria, viruses, toxic metals and organic pollutants that penetrated the soils. Participants believe this contamination of the environment to be extensive but exact levels are uncertain since no comprehensive studies have been conducted. Such contamination can have long-term consequences for the residents.

\section{Responsiveness analysis urban vs rural Talcahuano}

\subsection{Cross-sectoral response}

Table IV presents the results of the responsiveness analysis. In terms of cross-sectoral responsiveness, we found that the urban locality's responsiveness was adversely affected by the inadequate governmental response, particularly the poor execution of the warning process. Despite various international tsunami warnings, the Chilean professionals and

Urban Talcahuano: Rural Talcahuano:

Cross-sectoral response

Mobilization of actors and resources

Table IV. Responsiveness analysis: urban vs rural Talcahuano
Self-organization, cohesion and the households ability to address needs

Openness

Accountability

"the Plain" "the Bays"

$\begin{array}{ll}\text { L } & \text { M } \\ \text { L } & \text { H } \\ \text { L } & \text { H } \\ \text { L } & \text { H } \\ \text { L } & \text { M }\end{array}$


authorities discarded the possibility of a tsunami and told people to go back to tsunamiexposed lands. The people that obeyed were struck by tsunami waves and a number of people died in the process:

My instinct told me to get out and go up to higher ground. Not because of the sea, but because this is what you are always told to do so in case of something major like this. I never thought the sea would reach us. In fact, I just wanted to go to my parents' house, which is like the meeting point of my family. This is where everyone will come together and where we feel safe, together [...] We were about to go, when neighbors come back saying we should return to our homes because there is no tsunami warning. We also heard the firefighters and the marines say this. We were about to return when a man comes running to us, screaming "run, run, because the sea is coming." This is when the terror started [...]. As the water started to reach us, we ran and tried to find anything to hold on to. (Interview Talcahuano, February 12, 2014, number 2)

The rural locality's response was not affected by this deficiency. All participants expressed a reliance on their own and their community's collective judgment of the situation. They subsequently exited their dwellings as fast as they could and evacuated up to higher grounds making sure everyone could do the same: people helped each other get up the hill as quickly as possible. This points at households' and individuals' abilities to assess both earthquake and possible tsunami events. All participants from the rural community knew a major earthquake along the coastline could be accompanied by a tsunami and they were capable of interpreting natural warning signs to confirm their reasoning on February 27, 2010. The participants from the urban locality expressed their tsunami awareness was too latent and therefore easily overridden by the authorities' messages. Still, a significant number did evacuate up the hill. Mostly because they did not run into anyone telling them to do otherwise and thus relied either on instinct, based on latent knowledge, or other people's behavior or tsunami-related knowledge.

Even though the participants from the urban locality expressed limited tsunami-related knowledge, they did show earthquake-related knowledge. They were able to identify the magnitude of the telluric event and opt for fitting behavior: because of force and duration it was a telluric event greater than M7 that required the exit of the dwelling one is in. This has proven a successful strategy in Chile (Lomnitz, 1970).

\subsection{Self-organization, cohesion and ability to address needs}

From our data we gathered that participants from the rural locality organized themselves as soon as the earthquake stopped. This is when they made sure everyone, including those incapacitated, could evacuate to higher ground. The next morning, they quickly moved to dealing with the direct aftermath and ensuring short-term well-being. People would for instance, go down to get whatever was left to serve the community. Families tended to their own families first, but respondents stressed that everyone made sure surplus would be shared with others and especially with those who had lost everything:

We would fix everything together. The people that had not lost anything would share with those who did, we would cook and eat together and we would share all the relief we received. (Interview Talcahuano, February 5, 2014).

Respondents from the urban locality preferred a more inward-looking response. They focused on their own families and generally did not organize on a larger scale. From time-totime, neighborhood councils would organize collective actions to secure relief goods, but overall households kept to themselves and focused on their own recovery. This made the response more disparate and household-led. Each family started at their own pace and shaped their own recovery:

We immediately started cleaning our house [...] what was difficult to clean was the furniture which was all black and nasty. [My husband] cleaned it all [...] even the fridge [...] he patiently cleaned

Resilience in Talcahuano, Chile 
$\mathrm{DPM}$

28,5

596

the engine, washed it, dried it with a hairdryer [...] and it started working [...]. There was nothing one could do, but have patience and try to recover whatever could still function. (Interview Talcahuano, February 12, 2014, number 1)

(Lower) middle-class respondents shared their discomfort with the way the media led the mobilization and guidance of relief. They did not want to publicly, and often dramatically, broadcast their needs and be regarded as "needy." In their eyes, they were not "needy." It would take time, but they would be able to recover on their own through hard work and sacrifice. Today, these respondents remain far from recovery. This approach does not mobilize enough actors and resources to ensure a timely recovery. Moreover, their desire to remain silent makes them invisible (Engel, 2016).

\subsection{Mobilization of actors and resources}

Respondents from the rural locality mobilized and engaged a numerous actors and resources, locally, regionally, nationally and even internationally. This was aided by their organization and leadership. They had a single point of contact and a specific organization for managing incoming aid. Respondents regretted, though, that they were not able to align aid to needs. In their view this was because of lack of overall response and recovery doctrine and structure[3]. Everyone was just "winging it." Relief was for instance mostly spontaneous and supply-, rather than demand-driven. Respondents told us few donors would take communities' actual needs as a starting-point. This led to the arrival of a lot of clothes, but not to increasing economic contributions or assistance toward more qualitative housing options.

Respondents from the urban locality were unable to mobilize anything similar. In addition, they were unable to prevent actors from worsening their situation. For instance, they were unable to get a proper assessment and fixing of the actual tsunami damage to their homes. Also, on the wetlands residents were unable to prevent the government from using their lands as a garbage deposit and worsening the contamination of their lands. Their limited access to actors and resources led to slow recovery and possibly even worsened sensitivities.

\subsection{Openness}

Respondents from the rural locality showed more openness. They would, for instance, seek out opportunities to reconfigure their lives and fasten their recovery. Women found themselves applying for jobs at sea-side restaurants as soon as they were back in business. Other women sought out courses to roll-out small-scale enterprises selling for instance, seafood pies (empanadas de mariscos). In time, many women who had previously worked in fishery or had never worked before because work at sea is harsh, found themselves opportunities to work and support their families' recovery efforts. Eventually the men also got back to work and like this they were able to start getting life back on track, even though circumstances had obviously changed drastically.

Another good example of their flexibility and ability to adapt their conditions regards the homes that they received from the state. These were generally too small for the families. They solved this by negotiating that larger families would get larger plots. Then by reusing the materials of emergency dwellings, these families adapted their homes. Respondents share that their adaptability led them to a better situation. Many of them consider their lives today better than before $27 \mathrm{~F}$. They have more employment opportunities; they are no longer isolated and have access to different services, such as transportation, electricity, employment opportunities, sewage, water, etc. Some respondents feel their adaptability was significant because of the difficult circumstances they had known in "The Bays."

Respondents from the urban locality did not show similar patterns of openness. They appeared more passive and preferred sticking to what they knew. For instance, even though 
their needs grew in light of $27 \mathrm{~F}$, these people did not alter their perception of assistance. Despite their (understandable) need for substantial recovery relief that their personal networks could not provide, they refused to redefine themselves and address their need for public assistance even though this would mean a more extended recovery time. From our data we learned that an important motivation for this was their wish to not be considered a needy and/or unruly citizen.

\subsection{Accountability}

In terms of accountability, the rural locality's organization seemed characterized by transparency. They aimed for fairness and transparency. The idea was that everyone should be able to see and understand the recovery processes and consider it fair. Fair relates to people's idea of the processes being just, equitable and trustworthy. The leading organization came up with a specific method to guarantee this. For instance, there were clear rules and everything was done out in the open on one specific location known as "the mall": "everything was done openly, so that everyone could see (Interview Talcahuano, January 28, 2013)."

We did not encounter something similar for the urban locality. In fact, some participants relayed dissatisfaction with the way the aftermath and in particular relief was organized. For instance, the distribution of relief was largely guided by the media. The more media-attention a locality received, the more assistance would be ensured. Because of this some neighborhoods received hardly anything. Also, respondents mentioned some recovery processes were managed by leaders seeking enrichment of themselves and those close to them. According to these respondents, this led to irregularities.

\subsection{Synthesis}

The "after-action" analysis revealed that the localities experienced similar levels of damage, but responded quite differently. Even though the rural locality suffered substantial damage, their responsiveness made it possible to absorb impact and "bounce forward" (Manyena et al., 2011). We concluded they are "resilient." Their acceptance, endurance, flexibility and ability to seek out and take advantage of opportunities (adaptability) made it possible, at least for our respondents, to consider themselves better off than before. They recognize that they lost a lot, including "their" place, but they also realize that they gained access to valuable services and resources. They know that even without $27 \mathrm{~F}$, in time they would have had to make important changes to their way of life, largely due to the declining fish stock and their increasingly disadvantageous position in a contracting fish sector. These events made them make those changes a little sooner than expected. Today, their exposure to tsunamis is less. Their access to services and resources makes them less sensitive and exposed to hardship. The question is, though, will this negatively affect their capacity of response to similar future events? Will less variability diminish the capacity that in light of 27 facilitated their resilience? As our respondents mentioned, the improved situation offers fewer opportunities for cooperation among themselves and according to them this is affecting their cohesion and the prevalent solidarity. Time will tell.

We found the urban locality to be "susceptible" to earthquake/tsunami events. Damage was significant, but their responsiveness was not. Damage included loss of housing, labor options, opportunities, personal possessions, damage to health and well-being and natural capital, etc. The response was largely organized by individual households/families and was adversely affected by limited access to actors and resources. Many respondents were unable to appraise and respond appropriately to the events they faced during and after the earthquake/tsunami events. They did not mobilize relevant resources and actors, self-organize, seek and materialize opportunities, and address relevant recovery issues such as increasing soil contamination and the need for tsunami mitigation. Many were not able to "bounce back" to a similar situation, let alone bounce forward. A few even seem to

Resilience in Talcahuano, Chile 
$\mathrm{DPM}$ 28,5

have accommodated in a "new, but worse, normal." A normal characterized by more tsunami exposure, soil contamination, salt-water contamination of housing stock and limited resources. In light of this, our urban respondents seem generally worse off today than they were before $27 \mathrm{~F}$. In terms of vulnerability, this means that exposure remains the same, but that sensitivity has increased. Housing stock is most likely more sensitive and their resource stock has diminished by the costs they have had to bear to recover. Similarly, more people were actually exposed to the tsunami because of a failed institutional tsunami warning and this has left memories that are difficult to shake off. The list goes on. In terms of capacity of response, $27 \mathrm{~F}$ shows that it was minimal and we believe that it has decreased as a result of $27 \mathrm{~F}$. At the same time, tsunami awareness has increased and institutions are investing in more tsunami preparedness. The information received from our respondents suggests, however, that efforts remain minimal and do not address matters of exposure and sensitivity nor do they significantly improve capacity of response.

\section{Critical issues for disaster risk reduction strategies}

Too many processes tackling matters of disaster vulnerability remain top-down. This observation motivated this "after-action" resilience analysis. It is our contention that dealing with hazards requires drawing upon actions from the bottom up and strengthening community capacities (Gaillard, 2010, 2015; Mercer et al., 2012). Analyses like that presented in this paper are a first step: how do communities respond and what are capacities and challenges they face as they deal with natural hazards?

Policy documents and reports often stress the importance of inclusivity and the recognition of community-based assets (GNDR, 2011), but in practice this tends to translate into little more than consultation and/or information meetings in which community members are informed of upcoming plans or educated to enhance the perceived inadequate risk awareness throughout the community. This often results in frustration for everyone involved: frustration for the authorities/professionals involved because community members show limited enthusiasm or use the opportunity to express grievances and for the community because they do not feel taken seriously in the process at hand which they generally do consider important (Gaillard and Mercer, 2012; Cadag et al., 2017). Communities should, however, become leading. They are the ones at risk and the first responders when disaster strikes - "local communities nearly always constitute the first line of defense in facing disasters" (Gaillard, 2015, Kindle loc. 2670-2671). The problem is that making their experiences, narratives, knowledge, assets and capacities central to any disaster risk reduction process is difficult because their capacities rely "upon intangible resources (e.g. social network, folklore, memory of past events)" that need to be made tangible before they can foster dialogue among different DRR actors (Gaillard, 2015, Kindle loc. 1481).

In terms of governmental institutions, we saw how these can disrupt local and longstanding process and as such enhance negative vulnerability (see Section 5.1). DRR process are best build on asset analyses that reveal existing assets and limitations (Mercer et al., 2012; Gaillard, 2010, 2015). In this light, we want to share some observations that we believe policy makers could consider to ensure improved DRR processes:

(1) Governments should facilitate communities in overcoming critical issues that hamper their response to disasters and prevent them from bouncing forward. It is key that governments aim to enhance rather than replace communities' capacities and assets.

(2) To do this, it is key for governments to understand the communities' disaster risk response. The planning and implementation of institutional facilitation should thus be grounded on thorough disaster risk assessments highlighting communities' assets and capabilities as well as critical issues affecting communities' disaster vulnerability. 
(3) Since assets, capacities and critical issues can differ greatly per location, disaster risk analyses should be tailor made to the specific community and context.

(4) Finally, analyses should cover as many levels as possible and recognize and address all assets, capacities and critical issues even if some critical issues might involve the competency of authorities or professionals.

\section{Conclusion}

Through this study we wanted to learn about the forms of resilience that manifested in Talcahuano in response to $27 \mathrm{~F}$. We wanted to investigate actual resilience instead of forecasting. This is necessary in order to design and implement recovery and disaster risk reduction efforts but also to develop predictive models. With this in mind, we used a descriptive rather than a predictive model and appraised resilience in terms of damage and responsiveness. Also, to ensure experiences to remain leading throughout our analyses we opted for a qualitative method.

Our efforts exposed a resilient and a susceptible locality, both with their own strengths and weaknesses. Take the resilient locality, for instance. Before $27 \mathrm{~F}$ they were repeatedly affected by variability and hardship. This enabled resilience in the face of $27 \mathrm{~F}$. At the same time, this source of resilience implied limited stability and security, i.e. unfavorable conditions for development. Today, they find themselves living more favorable conditions for progress. But will this translate into reduced capabilities to deal with future disruptions? These observations and questions should guide disaster risk reduction efforts. Similarly, the precariousness of the households in the susceptible locality warrants increasing attention. Households' vulnerability is not straightforward and it is not the same as poverty. We found middle-class households facing increasingly precarious conditions since $27 \mathrm{~F}$. Again, more in-depth knowledge about this vulnerability is key for any disaster risk reduction trajectory in this area.

Ideally, this study will be complemented, also by mixed studies including quantitative dimensions. This would enrich and deepen the existing scientific and practical knowledge. In that sense, this paper was intended to start the ball rolling and work toward resilience analyses "before" and "after" events to ensure that both communities' and institutions' strengths and weaknesses are appraised and well-grounded and responsible paths toward disaster risk reduction are secured.

\section{Notes}

1. The analysis is referred to as an "after-action" resilience analysis because the appraisal was done in the wake of the 2010 earthquake/tsunami event.

2. We did not adopt Cai et al.'s framework because we felt their adaptations were not always consistent with our understanding of resilience. For instance, in our view we take exposure as a given and just look at the response and damage. We find it challenging to determine that a locality's resilience that is less exposed or not exposed at all to an event will be compared to one that is. Also, we understand vulnerability as vulnerability to change and stress which we do not necessarily relate to socioeconomic aspects. There are various studies that have shown that poorer societies, because of the high levels of variability they live with on a daily basis, are highly resilient. Having a phone does therefore not necessarily relate to limited resilience. In fact, in our study phones proved absolutely useless in terms of response and recovery resilience since networks had collapsed. Resilience seems more equated with the way communities respond to such changes in their environments.

3. Doctrine refers to the established and agreed upon core beliefs and principles defined to guide and inform emergency management. Both doctrine and structure should be described in the core emergency management documents. 
DPM

28,5

600

\section{References}

Aldunce, P., Beilin, R., Handmer, J. and Howden, M. (2014), "Framing disaster resilience: the implications of the diverse conceptualisations of 'bouncing back'", Disaster Prevention and Management, Vol. 23 No. 3, pp. 252-270.

Anderson, M.B. and Woodrow, P.J. (1998), Rising from the Ashes: Development Strategies in Times of Disaster, Westview Press, Boulder, CO.

Bahadur, A.V., Ibrahim, M. and Tanner, T. (2010), "The resilience renaissance? Unpacking of resilience for tackling climate change and disasters", SCR Discussion Paper No. 1, Institute of Development Studies, Brighton, available at: www.gov.uk/dfid-research-outputs/the-resiliencerenaissance-unpacking-of-resilience-for-tackling-climate-change-and-disasters-scr-discussionpaper-1 (accessed October 28, 2018).

Batista, W.B. and Platt, W.J. (2003), "Tree population responses to hurricane disturbance: syndromes in a south-eastern USA old-growth forest”, Journal of Ecology, Vol. 91 No. 2, pp. 197-212.

Bellingham, P.J., Tanner, E.V.J. and Healey, J.R. (1995), "Damage and responsiveness of Jamaican Montane tree species after disturbance by a hurricane", Ecology, Vol. 76 No. 8, pp. 2562-2580.

Bruneau, M., Chang, S.E., Eguchi, R.T., Lee, G.C., O’Rourke, T.D., Reinhorn, A.M., Shinozuka, M., Tierney, K., Wallace, W.A. and Von Winterfeldt, D. (2003), "A framework to quantitatively assess and enhance the seismic resilience of communities", Earthquake Spectra, Vol. 19 No. 4, pp. 733-752.

Bucci, F. (2013), "La complicidad de la planificaciónurbana en la creación de territorios en riesgo: el caso de las inundacionesurbanas en la ciudad-puerto de Talcahuano. Seminario para optar al Título Profesional de Administrador Público con Menciónen Gestión Pública”, unpublished manuscript, Universidad de Concepción, Concepción.

Cadag, J.R., Driedger, C., Garcia, C., Duncan, M., Gaillard, J.C., Lindsay, J. and Haynes, K. (2017), "Fostering participation of local actors in volcanic disaster risk reduction", in Fearnley, C.J., Bird D.K., Haynes K., McGuire, W.J. and Jolly, G. (Eds), Observing the Volcano World, An Official Book Series of the International Association of Volcanology and Chemistry of the Earth's Interior - IA VCEI, Advances in Volcanology, Springer, Barcelona and Cham, pp. 481-497.

CADRI (2011), Basics of Capacity Development for Disaster Risk Reduction, Capacity for disaster reduction initiative, Geneva, available at: www.cadri.net/sites/default/files/18061_cadribrochureweb2_0.pdf (accessed July 9, 2018).

Cai, H., Lam, N.S.N., Zou, L., Qiang, Y. and Li, K. (2016), “Assessing community resilience to coastal hazards in the Lower Mississippi River Basin”, Water, Vol. 8 No. 2, pp. 1-18, available at: http://dx. doi.org/10.3390/w8020046

De Groeve, T., Poljansek, K., Ehrlich, D. and Corbane, C. (2014), “JRC scientific and policy reports - current status and best practices for disaster loss data recording in EU member states: a comprehensive overview of current practice in the EU member states", available at: www.irdrinternational.org/wpcontent/uploads/2015/04/JRC-SOTA-Loss-Report_11182014.pdf (accessed July 9, 2018).

EC (2015), "JRC science and policy reports - guidance for recording and sharing disaster damage and loss data: towards the development of operational indicators to translate the Sendai framework into action”, Report EUR 27192 EN, European Commission, available at: http://drr.jrc.ec.europa. eu/Portals/0/Loss/JRC_guidelines_loss_data_recording_v10.pdf (accessed July 9, 2018).

ECLAC (2003), Handbook for Estimating the Socio-Economic and Environmental Effects of Disasters, United Nations Economic Commission for Latin America and the Caribbean, Mexico City, available at: http://web.worldbank.org/WBSITE/EXTERNAL/TOPICS/EXTURBANDE VELOPMENT/EXTDISMGMT/0,contentMDK:20196047 menuPK:1415429 pagePK:2100 58 piPK:210062 theSitePK:341015,00.html (accessed July 9, 2018).

Engel, K., Frerks, G., Velotti, L., Warner, J. and Weijs, B. (2014), "Flood disaster subcultures in the Netherlands: the parishes of Borgharen and Itteren", Natural Hazards, Vol. 73 No. 2, pp. 859-882.

Engel, K.E. (2016), “Talcahuano, Chile, in the wake of the 2010 disaster: a vulnerable middle?", Natural Hazards, Vol. 80 No. 2, pp. 1057-1081. 
Gaillard, J.C. (2010), "Vulnerability, capacity, and resilience: perspectives for climate and development policy", Journal of International Development, Vol. 22 No. 2, pp. 218-232.

Gaillard, J.C. (2015), People's Response to Disasters in the Philippines: Vulnerability, Capacities and Resilience (Disaster Studies), Kindle ed., Palgrave Macmillan, New York, NY.

Gaillard, J.C. and Mercer, J. (2012), "From knowledge to action: bridging gaps in disaster risk reduction", Progress in Human Geography, Vol. 37 No. 1, pp. 93-114.

Gallopín, G.C. (2006), "Linkages between vulnerability, resilience, and adaptive capacity", Global Environmental Change, Vol. 16 No. 3, pp. 293-303.

GNDR (2011), "If we do not join hands: views from the frontline-local reports of progress on implementing the Hyogo Framework for action, with strategic recommendations for more effective implementation", Global Network of Civil Society Organizations for Disaster Reduction, Teddington, available at: www.preventionweb.net/files/19857_gnreport20111.pdf (accessed April 22, 2019).

Gunderson, L.H. and Holling, C.S. (2002), Panarchy Understanding Transformations in Human and Natural Systems, Kindle ed., Island Press, Washington, DC.

Jovel, R.J. and Muhadar, M. (2010), "Damage, loss, and needs assessment: guidance notes: Volume 1. Design and Execution of a Damage, Loss, and Needs Assessment”, World Bank, Washington, DC, available at: https://openknowledge.worldbank.org/handle/10986/19047 (accessed April 22, 2019).

Lomnitz, C. (1970), "Casualties and behavior of populations during earthquakes", Bulletin of the Seismological Society of America, Vol. 60 No. 4, pp. 1309-1313.

Manyena, B. (2016), “After Sendai: is Africa bouncing back or bouncing forward from disasters?", International Journal of Disaster Risk Science, Vol. 7 No. 1, pp. 41-53.

Manyena, B., O’Brien, G., O’Keefe, P. and Rose, J. (2011), "Disaster resilience: a bounce back or bounce forward ability?", Local Environment: The International Journal of Justice and Sustainability, Vol. 16 No. 5, pp. 417-424.

Manyena, S.B. (2006), “The concept of resilience revisited”, Disasters, Vol. 30 No. 4, pp. 434-450.

Mercer, J., Gaillard, J.C., Crowley, K., Shannon, R., Alexander, B., Day, S. and Becker, J. (2012), "Culture and disaster risk reduction: lessons and opportunities", Environmental Hazards, Vol. 11 No. 2, pp. 74-95.

Mitchell, T. and Harris, K. (2012), "Resilience: a risk management approach", available at: www.odi.org/ sites/odi.org.uk/files/odi-assets/publications-opinion-files/7552.pdf (accessed July 9, 2018).

NOAA (2010), “Chile Tsunami - Feb 27, 2010”, December 12, available at: https://youtu.be/nZ9Du7VfdSg (accessed November 4, 2018).

Parsons, M., Glavac, S., Hastings, P., Marshall, G., McGregor, J., McNeill, J., Morley, P., Reeve, I. and Stayner, R. (2016), "Top-down assessment of disaster resilience: a conceptual framework using coping and adaptive capacities", International Journal of Disaster Risk Reduction, Vol. 19, October, pp. 1-11, available at: https://doi.org/10.1016/j.ijdrr.2016.07.005

Scott, Z. and Few, R. (2016), "Strengthening capacities for disaster risk management: insights from existing research and practice", International Journal of Disaster Risk Reduction, Vol. 20, December, pp. 145-153.

Scott, Z., Wooster, K., Few, R., Thomson, A. and Tarazona, M. (2016), "Monitoring and evaluating disaster risk management capacity", Disaster Prevention and Management, Vol. 25 No. 3, pp. $412-422$.

Sehnbruch, K. (2017), "The impact of the Chilean earthquake of 2010: challenging the capabilities of the Neoliberal State", Latin American Perspectives, Vol. 44 No. 4, pp. 4-9.

Solimano, A. (2014), Chile and the Neoliberal Trap, Cambridge Books, Cambridge.

Sudmeier-Rieux, K. (2014), "Resilience - an emerging paradigm of danger or of hope?", Disaster Prevention and Management, Vol. 23 No. 1, pp. 67-80.

Toseroni, F., Romagnoli, F. and Marincioni, F. (2016), "Adapting and reacting to measure an extreme event: a methodology to measure disaster community resilience", Energy Procedia, Vol. 95, September, pp. 491-498.

Resilience in Talcahuano, Chile 
$\mathrm{DPM}$

28,5

602

UNDP and Municipality of Talcahuano (2012), Guia participativa de orientaciones de respuesta frente a emergencias de terremoto-tsunami a partir de la experiencia de Talcahuano, Chile, UNDP, Santiago de Chile, available at: www.cl.undp.org/content/chile/es/home/library/crisis_ prevention_and_recovery/publication_2.html (accessed July 9, 2018).

UNDP and the Municipality of Talcahuano (2011), Plan de recuperación post desastre con enfoque de gestión de riesgo y participación ciudadana, Comuna de Talcahuano, Región del Biobio, Chile, UNDP, Santiago de Chile, available at: http://www.cl.undp.org/content/chile/es/home/library/ crisis_prevention_and_recovery/publication_9.html\# (accessed July 9, 2018).

UNDP and the Municipality of Talcahuano (2016), "Estrategias territoriales para la reducción del riesgo de desastre", available at: www.slideshare.net/ObservatorioRRD/estrategias-territorialespara-la-reduccin-del-riesgo-de-desastre-talcahuano-chile (accessed July 9, 2018).

USGS (2018), Interactive Map of the M8.8 Offshore Bio-Bio, USGS, Denver, available at: https:// earthquake.usgs.gov/earthquakes/eventpage/official20100227063411530_30/map (accessed November 4, 2018).

Vidal, C. and Romero, H. (2010), "Efectos ambientales de la urbanización de las cuencas de los ríos BíoBío y Andalién sobre los riesgos de inundación y anegamiento de la ciudad de Concepción”, in Pérez, L. and Hidalgo, R. (Eds), Concepción metropolitano (AMC). Planes, procesos y proyectos, GEOlibros Pontificia Universidad Católica, Santiago de Chile, available at: http://bitstream/handle/2250/118084/ EfectosAmbientalesde.pdf?sequence=1\&isAllowed=y (accessed July 9, 2018).

Walker, B. and Salt, D. (2006), Resilience Thinking: Sustaining Ecosystems and People in a Changing World, Kindle ed., Island Press, Washington, DC.

Walker, B., Holling, C.S., Carpenter, S.R. and Kinzig, A. (2004), "Resilience, adaptability and transformability in social-ecological systems", Ecology and Society, Vol. 9 No. 2, p. 5.

Warner, J. and Engel, K. (2014), “Disaster culture matters”, Ambiente \& Sociedade, Vol. 17 No. 4, pp. 1-8.

Wisner, B., Blaikie, P.M., Cannon, T. and Davis, I. (2004), At Risk: Natural Hazards, People's Vulnerability and Disasters, Routledge, London.

Corresponding author

Karen Elisabeth Engel can be contacted at: k.e.engel@gmail.com

For instructions on how to order reprints of this article, please visit our website:

www.emeraldgrouppublishing.com/licensing/reprints.htm

Or contact us for further details: permissions@emeraldinsight.com 